\title{
COUNTER APPLICATION TRAINER FOR TEACHING AIDS IN DIGITAL ELECTRONIC COURSE
}

\author{
Ahmad Rizal Madar', Sri Sumarwati ${ }^{2, ~ *}$, Hashima Hamid ${ }^{3}$, Mohd Hasril Amiruddin ${ }^{4}$, \\ Nor Athirah Musa ${ }^{5}$ \\ 1,2,3,5 Universiti Tun Hussein Onn Malaysia, Parit Raja, Batu Pahat, 86400 Johor, Malaysia \\ ${ }^{4}$ Universitas Swadaya Gunung Jati, J1. Pemuda No. 32, Cirebon, Jawa Barat 45132, Indonesia \\ E-mail: sri fatoni78@yahoo.com* \\ *Corresponding Author
}

\begin{abstract}
Teaching aids play a vital role in the teaching and learning process. Teaching aids are crucial in helping students comprehend learning theory. However, most existing counter application trainers as teaching aids in digital electronics courses are developed without following the syllabus in vocational colleges and come at a high price. This study aimed to develop a counter application as teaching aids in digital electronics courses to provide low-cost teaching aids tailored to the curriculum at vocational colleges. This quantitative research applied the Life Development System (SDLC) model. This study developed a counter application trainer for teaching the Electronic and Digital Application course in vocational colleges. The findings showed that the product has been validated by experts based on the product design, suitability, and functionality. Further investigation could be conducted by looking into the trainer's safety features, such as adding a cap to the transformer's supply circuit and the on/off switch. Electric shock can be avoided with this cover.
\end{abstract}

Keywords: counter application trainer, digital electronic course, teaching aids

\section{INTRODUCTION}

The Ministry of Education Malaysia has offered programs that enable potential students to be partially professional in technical and vocational. In this regard, the role of instructors in technical and vocational is increasingly challenging. Vocational education emphasizes two aspects of the study, namely theory and practice [1]. The industry focuses on human resources who have the knowledge and skills in their areas of expertise [2], [3]. Therefore, lecturers need to diversify the appropriate teaching methods during the teaching and learning process.

The teaching and learning process is crucial to produce highly skilled and knowledgeable students [4]. Pedagogy is the strategy of how a lesson is delivered through the teaching and learning process to get results [5]. Therefore, to ensure that the teaching and learning process is effective, teaching aids play a crucial role [6]. Tamuri \& Yusoff [7] stated that the use of teaching aids appropriate to the cognitive level of students can facilitate selflearning based on their learning needs.

The use of teaching aids can provide students with information on something related to subjects taught more clearly and systematically in teaching. Teaching aids can help technical teachers explain things and concepts of learning content more accurately than verbal explanations [8], [9].

Learning theory alone is not enough for an individual to become competent or proficient in hands-on skills [10]. The use of teaching aids can help technical teachers explain things and concepts of learning content more accurately than oral explanations [11]. Therefore, teachers should be creative in their teaching by increasing their use of teaching aids. The use of teaching aids in teaching and learning has identified many positive effects on students [12]. Teaching aids can attract students to understand a concept to create an active teaching and learning environment [13]. However, teachers ' teaching methods are less effective in improving students' understanding. 
Reighluth [14] found that there are still many teachers who use whiteboards to convey content information to students which at the same time does not provide intelligence to students. Students are unable to concentrate on learning because they consider the topic of learning uninteresting. The effects of this situation cause the student's concentration to be impaired. Therefore, students are not interested in actively pursuing learning. The results of a study by Mohd Noor \& Ahmad [15] show that there are still teachers who use the method of reading textbooks only in their teaching and cause students to be less interested in being active in the classroom. Accordingly, there are only a few students who can clearly understand what the teacher is teaching.

Teaching aids are beneficial for the process of teaching and learning [16]. Many studies have demonstrated the significance of teaching aid in supporting learning [8], [13], [17], [18]. Dawi [19] explained that education is closely related to teaching aids in facilitating the teaching and learning process. The teaching aids are one of the alternatives used by teachers to deliver teaching content [20]. Sulaiman [21] suggested that teaching aids are the most crucial factor in determining the success of learning programs, stimulating students' desire to know something. Teaching aids can make it easier for students to understand the learning [22], [23]. Teachers must utilize teaching aids to enhance students' knowledge and understanding [24]. Therefore, this study aimed to develop a counter application trainer for teaching aids in digital electronics courses to provide low-cost teaching aids that are tailored to the curriculum at vocational colleges.

\section{METHOD}

The counter application trainer is a very widely used component in digital circuits, and is manufactured using separate integrated circuits, and is also included as part of larger integrated circuits. The design for this counter application trainer used the Systems Development Life
Cycle (SDLC) model namely analyze, design, implementation, testing, and evaluation as presented in Figure 1.

This study focuses on the subtopic of Interpreting Counter and Register for DEB 2142 Digital Electronic course at Vocational College. The evaluation phase involved three experts selected with purposive sampling. The experts consist of three lecturers from the Faculty of Technical and Vocational Education in Universiti Tun Hussein Onn Malaysia (UTHM). In this phase, the researchers distribute questionnaires to experts to evaluate the counter application trainer in the aspects of design, suitability, and functionality. The questionnaire consisted of 17 items to identify the opinions of experts about their consent. Data in the evaluation phase were analyzed using descriptive analysis, namely frequency, and percentage.

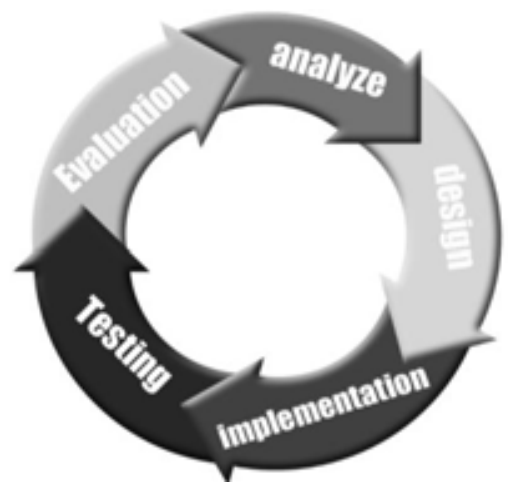

Figure 1. Systems Development Life Cycle (SDLC)

\section{RESULTS AND DISCUSSION}

This study aimed to develop a counter application trainer for teaching aids in the digital electronic course. This project involves five phases, namely analysis, design, implementation, testing, and evaluation.

The first phase is the analysis phase. In the analysis phase, it was found that various teaching aids have been produced in the market including trainers. Each trainer has developed with its specifications and advantages or disadvantages. Most existing trainers are developed by other countries such as India and Germany. That is why the production of 
trainers that exist in the market does not follow the syllabus in vocational colleges for the teaching and learning process. There is also a counter application trainer that has a variety of applications however the price is costly.

The second phase is the design phase. Aspects to consider in designing teaching aids include the fact that they are affordable and can be developed collaboratively by teachers and students under the supervision of teachers. Besides, teaching aids should be available, affordable, safe, easy to use, and durable when used in the classroom. Therefore, this study designed a circuit that can be used by vocational college students. The design phase was a process involving casing design and layout design. The casing was the construction or design of a product. The casing design for this trainer was A3 paper size of $420 \mathrm{~mm} \times$ $297 \mathrm{~mm} \times 110 \mathrm{~mm}$ as illustrated in Figure 2.

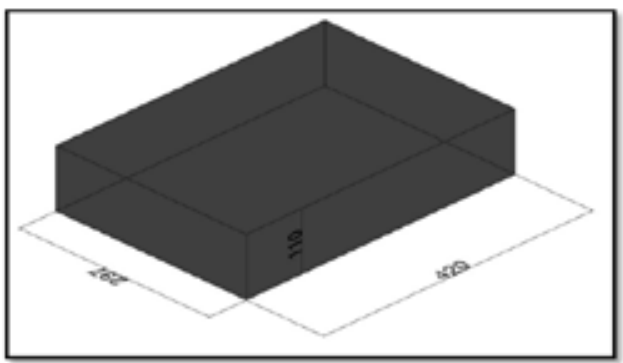

Figure 2. Casing Design

A layout design was a plan for the layout of the circuit or components. The layout was located at the top of the casing and it was the area to make connections where each component would represent the schematic circuit as shown in Figure 3.

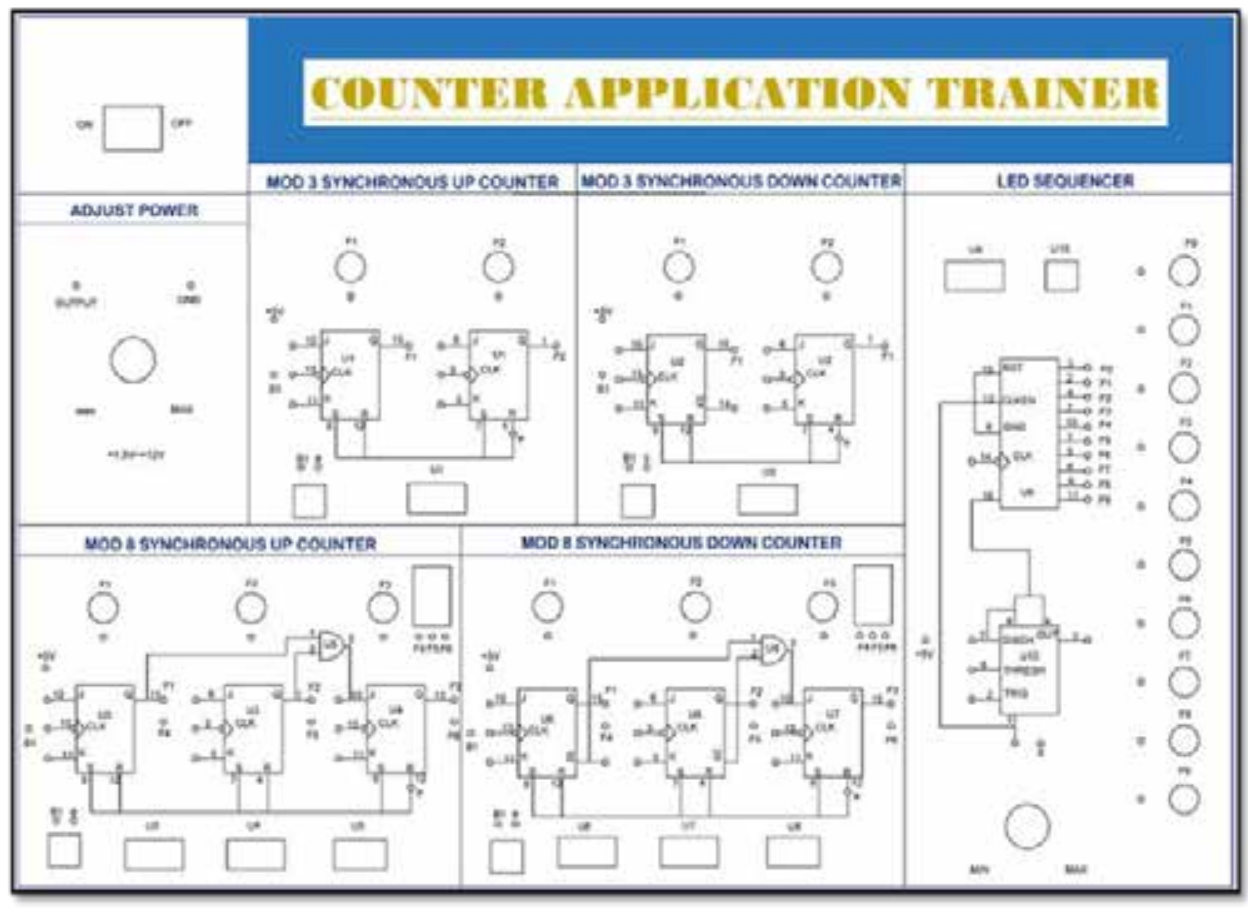

Figure 3. Layout Design

The third phase is the implementation phase. The researchers need to emphasize the cost aspect so that the overall cost of the product was commensurate with the function of the product. The findings of this study showed that the total cost of the product was RM 253.00. Researchrs selected key ingredients that were easily found in any store. In addition, the materials also need to have durability because the nature of the component such as the transformer was heavy and requires a strong material to withstand it. The components and materials are listed in Table 1. 
$\underline{\text { Table 1. List of Components and Materials Cost }}$

\begin{tabular}{|c|c|c|c|c|}
\hline No & $\begin{array}{c}\text { Components } \\
\text { and Materials }\end{array}$ & Quantity & Cost/Unit & Total \\
\hline 1 & $\mathrm{IC}=\mathrm{CD} 4027$ & 6 & RM 3.00 & RM 18.00 \\
\hline 2 & $\mathrm{IC}=\mathrm{CD} 4081$ & 2 & RM 3.30 & RM 6.60 \\
\hline 3 & $\mathrm{IC}=\mathrm{CD} 4017$ & 1 & RM 1.70 & RM 1.70 \\
\hline 4 & $\mathrm{IC}=$ Timer 555 & 1 & RM 1.20 & RM 1.20 \\
\hline 5 & $\begin{array}{l}\text { Resistors }= \\
470 \Omega\end{array}$ & 20 & RM 0.50 & RM 10.00 \\
\hline 6 & $\begin{array}{l}\text { Resistors }=1 \mathrm{M} \\
\Omega\end{array}$ & 14 & RM 0.50 & RM 7.00 \\
\hline 7 & $\begin{array}{l}\text { Potential } \\
\text { meter }=100 \mathrm{k} \Omega\end{array}$ & 1 & RM 1.50 & RM 1.50 \\
\hline 8 & $\begin{array}{l}\text { Capacitor= } \\
10 \mathrm{uF}\end{array}$ & 2 & RM 0.50 & RM 1.00 \\
\hline 9 & LED & 20 & RM 1.00 & RM 20.00 \\
\hline 10 & $\begin{array}{l}\text { Seven } \\
\text { Segment } \\
\text { Display }\end{array}$ & 2 & RM 1.00 & RM 2.00 \\
\hline 11 & $\begin{array}{l}\text { Banana Bullet } \\
\text { Connector }\end{array}$ & 80 & RM 0.50 & RM 40.00 \\
\hline 12 & Acrylic & 1 & RM 60.00 & RM 60.00 \\
\hline 13 & Rocker Switch & 1 & RM 3.00 & RM 3.00 \\
\hline 14 & Strip Board & 5 & RM 5.00 & RM 25.00 \\
\hline 15 & Socket IC & 10 & RM 0.40 & RM 4.00 \\
\hline 16 & Push Button & 4 & RM 0.60 & RM 2.40 \\
\hline 17 & Transformer & 1 & RM 20.00 & RM 20.00 \\
\hline 18 & $\begin{array}{l}\text { Wire One } \\
\text { Core }\end{array}$ & 1 & RM 30.00 & RM 30.00 \\
\hline & TOTAL & & & RM 253.00 \\
\hline
\end{tabular}

In the implementation phase, the first step was to test components and circuits. This was to ensure that this designed circuit worked well and was not misplaced from the stated objectives. The test of this circuit involved all the blocks to be developed namely blocks A, B, $\mathrm{C}, \mathrm{D}$, and $\mathrm{E}$. After the process of developing the layout, casing, and circuit testing and components were completed, the researchers conducted the installation process on the stripboard for the components. Wiring between component and bullet connector was performed using a single core.

The next phase is the testing phase. Functionality testing is circuit testing to determine if this developed trainer works well or not. The results are presented in Table 2. For the testing phase, the researchers had selected the materials and tools used in the development of Counter Application Trainer for the DEB 2142 Digital Electronic and Application course for students at Vocational College.

Table 2. Circuit Testing

Circuit
$\begin{aligned} & \text { Mod } 3 \\ & \text { Up Counter } \\ & \text { Circuit }\end{aligned}$

Mod 3

Synchronous

Down Counter

Circuit

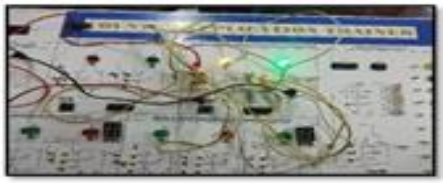

Mod 8

Synchronous

Down Counter

Circuit

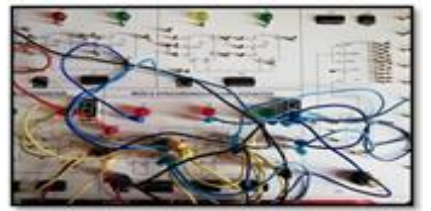

Mod 8

Synchronous

Up Counter

Circuit

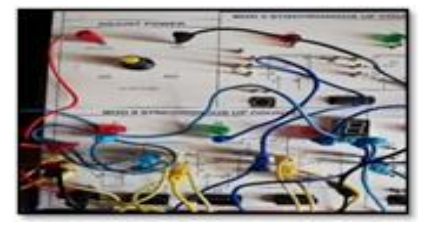

LED Sequence Circuit

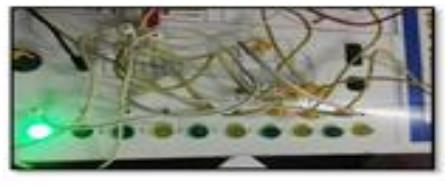

This connection is based on the Mod 3 Synchronous Down Counter circuit in the practical research paper. This circuit is a 2bit synchronous counter circuit. Input source is taken from $5 \mathrm{~V}$ DC power supply.

This connection is based on the Mod 8 Synchronous Down Counter circuit in the practical research paper. This circuit is a 3bit synchronous counter circuit. The input source is taken from a $5 \mathrm{~V} \mathrm{DC}$ power supply. However, the functionality of this circuit is not working when supplies are supplied

This connection is based on the Mod 8 Synchronous Up circuit in the practical research paper. This circuit is a 3-bit synchronous counter circuit. The input source is taken from a $5 \mathrm{~V}$ DC power supply. However, the functionality of this circuit is not working when supplies are supplied

This connection is based on the LED Sequencer circuit in the practical test paper. This circuit is a running light circuit. Input source is taken from $5 \mathrm{~V}$ DC power supply 
The last phase is the evaluation phase. In the evaluation phase, experts were selected using purposive sampling. The experts consisted of three lecturers from the Faculty of Technical and Vocational Education in Universiti Tun Hussein Onn Malaysia (UTHM). The results of the evaluation on the design of the counter application trainer were based on research expert judgments as shown in Table 3.

Based on the findings in Table 3, the experts stated that the design of this trainer was good and attractive. The design was easy to understand and the layout of the components was attractive. Furthermore, this trainer had a suitable size for use in practical classes because the size was neither too big nor too small. The experts also suggested that the neatness of the circuit should be trimmed.

Table 3. Evaluation of the Design of the Counter Application Trainer

\begin{tabular}{lcccc}
\hline \multirow{2}{*}{ Item } & \multicolumn{2}{c}{ Frequency } & \multicolumn{2}{c}{ Percentage } \\
& Yes & No & Yes & No \\
\hline $\begin{array}{l}\text { Neatness mounting } \\
\text { components on the }\end{array}$ & 3 & 0 & $100 \%$ & $0 \%$ \\
strip board & & & & \\
$\begin{array}{l}\text { The composition of } \\
\text { the components on }\end{array}$ & 3 & 0 & $100 \%$ & $0 \%$ \\
$\begin{array}{l}\text { the stripboard } \\
\text { regularly }\end{array}$ & & & & \\
$\begin{array}{l}\text { The product has an } \\
\text { interesting design }\end{array}$ & 2 & 1 & $66.67 \%$ & $33.33 \%$ \\
$\begin{array}{l}\text { The design of the } \\
\text { product is user }\end{array}$ & 3 & 0 & $100 \%$ & $0 \%$ \\
$\begin{array}{l}\text { friendly } \\
\text { Selection of } \\
\text { appropriate hardware }\end{array}$ & & & & \\
\hline
\end{tabular}

The findings of the evaluation on the suitability of the counter application trainer were based on evaluation from research experts as shown in Table 4. This counter application trainer was acceptable in terms of product suitability since it could be used to assist vocational college students to better understand the lessons through practical training. This is in line with Meeks [3] who reported that teaching aids could stimulate students' interest and attract them in understanding the content more effectively.

Table 4. Evaluation of the Suitability of the Counter Application Trainer

\begin{tabular}{lcccc}
\hline \multicolumn{1}{c}{ Item } & \multicolumn{2}{c}{ Frequency } & \multicolumn{2}{c}{ Percentage } \\
& Yes & No & Yes & No \\
\hline $\begin{array}{l}\text { The product meets the } \\
\text { needs of users } \\
\text { (Vocational College }\end{array}$ & 3 & 0 & $100 \%$ & $0 \%$ \\
$\begin{array}{l}\text { Students) } \\
\text { The trainer can assist } \\
\text { the user in practice. }\end{array}$ & 3 & 0 & $100 \%$ & $0 \%$ \\
$\begin{array}{l}\text { The position of the } \\
\text { components on the } \\
\text { trainer is appropriate }\end{array}$ & 3 & 0 & $100 \%$ & $0 \%$ \\
$\begin{array}{l}\text { The size of the } \\
\text { product is suitable for } \\
\text { the users }\end{array}$ & 3 & 0 & $100 \%$ & $0 \%$ \\
$\begin{array}{l}\text { Providing security } \\
\text { features for the users }\end{array}$ & 3 & 0 & $100 \%$ & $0 \%$ \\
\hline
\end{tabular}

The results of the evaluation on the functionality of the counter application trainer were based on assessments from experts as shown in Table 5. The results showed that the trainer works well and was suitable for use as teaching aids in vocational colleges. Experts also recommended emphasizing the usage of integrated circuit (IC) components because these components are very sensitive and can cause the circuit to fail.

Table 5. Evaluation of the Functionality of the Counter Application Trainer

\begin{tabular}{lcccc}
\hline \multicolumn{1}{c}{ Item } & \multicolumn{2}{c}{ Frequency } & \multicolumn{2}{c}{ Percentage } \\
\cline { 2 - 5 } & Yes & No & Yes & No \\
\hline $\begin{array}{l}\text { The product works } \\
\text { effectively }\end{array}$ & 3 & 0 & $100 \%$ & $0 \%$ \\
$\begin{array}{l}\text { Circuits can show } \\
\text { appropriate application }\end{array}$ & 3 & 0 & $100 \%$ & $0 \%$ \\
$\begin{array}{l}\text { for students } \\
\text { knowledge }\end{array}$ & & & & \\
$\begin{array}{l}\text { The circuit can be } \\
\text { connected using the } \\
\text { right tools }\end{array}$ & 2 & 1 & $66.67 \%$ & 33.33 \\
$\begin{array}{l}\text { The LED light works } \\
\text { well }\end{array}$ & 3 & 0 & $100 \%$ & $0 \%$ \\
$\begin{array}{l}\text { The display on seven } \\
\text { segments is good }\end{array}$ & 3 & 0 & $100 \%$ & $0 \%$ \\
$\begin{array}{l}\text { The function of } \\
\text { application circuit } \\
\text { performs well }\end{array}$ & 3 & 0 & $100 \%$ & $0 \%$ \\
$\begin{array}{l}\text { ON/OFF switch works } \\
\text { properly }\end{array}$ & 2 & 0 & $100 \%$ & $0 \%$ \\
\hline
\end{tabular}


The first element in developing a product is to design the product. The design that needs to be built at the beginning of the development is an overview of the product to be developed and can attract students' interest in understanding this subtopic of the counter. The description consists of the size, shape, and use of materials.

This finding is in line with the study of Durdanovic [25], who stated that teaching aids can stimulate high interest and attract students in understanding the content being studied more effectively. In designing this product, the researchers emphasized two aspects namely safety and comfort. It should be appropriate to the environment and the necessary emphasis such as physical features, color, material selection, and variety of sources. In terms of safety aspects, the researchers selected the safest materials by replacing the use of wood or board with perspex. This is because perspex is better than wood or board since it is waterproof and durable.

Based on the design of this counter application trainer, the experts agree that this developed design was appropriate for usage by students because it was medium in size and light in weight, making it easy to carry. Experts also concluded that the layout was attractive and well-organized.

The researchers have found that the students were not very exposed to the subtopic of counters. Individual differences between pupils exist; some intelligent students can understand merely by learning the theory, while others are rather slow because they are unable to comprehend it. This finding corresponds with Jafre \& Abidin [26] who concluded that learning style impacts students' overall achievement. In addition, the lack of equipment and trainers has also hampered the teaching and learning process. Therefore, the purpose of this study is to help students better understand and be able to do practical learning. The researchers have defined the use of push switches as clocks. This is because by using a push switch, the students will assign the clock to the circuit on their own for the circuit to operate.

In addition, researchers have developed five sets of practical experimental papers. This practical experiment paper, allows students to make reinforcement on the sub-topics of interpreting counter and register. At each activity performed, students can figure out and examine how each counter mode's sequence differs. Based on the suitability in developing this product, the researcher found that the experts agreed that the development of this counter application trainer was in line with the content of the syllabus in the vocational college. Furthermore, the availability of this trainer can assist students in gaining a deeper understanding of the subtopics of interpreting counter and register.

\section{CONCLUSION}

Teaching aids are required in the process of teaching and learning. The use of teaching aids is crucial in helping students understand the teaching of theory better. This study aimed to develop a counter application for teaching aids in digital electronics courses. The findings indicated that the expert has validated this product based on its design, product compatibility, and functionality. This study successfully developed the counter application trainer as a teaching aid for the Electronic and Digital Application course in vocational colleges. Suggestions for further research were by exploring the safety aspects of the trainer by adding a cap on the supply circuit of the transformer and the switch ON/OFF trainer. This cover can protect users from electric shock. Besides, the researchers in the future need to avoid damaging the circuit because it can cause the development process of the counter application trainer to be slow. Furthermore, in the future, researchers must avoid damaging the circuit because this will cause the growth of the counter application trainer to be delayed and unsuccessful. 


\section{ACKNOWLEDGMENT}

This study was supported by Universiti Tun Hussein Onn Malaysia (UTHM) through PPG (vot K012).

\section{REFERENCES}

[1] M. Fjellström, "Vocational education in practice: a study of work-based learning in a construction programme at a Swedish upper secondary school," Empir. Res. Vocat. Educ. Train. 2014 61, vol. 6, no. 1, pp. 1-20, Jan. 2014, doi: 10.1186/1877-6345-6-2.

[2] S. Atiqah Shahrudin, "Faktor yang Mempengaruhi Keberkesanan Pengajaran dan Pelajaran di dalam Bengkel Vokasional di Dua Buah Sekolah Menengah Teknik di Negeri Sembilan," Universiti Teknologi Malaysia, 2008.

[3] G. A. Meeks, "Critical Soft Skills to Achieve Success in the Workplace," Walden University, 2017.

[4] N. H. Mohamed, "Penglibatan Pelajar dalam Pembelajaran Koperatif di Sekolah Menengah Vokasional. Fakulti Pendidikan Teknikal dan Vokasional," Universiti Tun Hussein Onn Malaysia, 2012.

[5] C. Rapanta, L. Botturi, P. Goodyear, L. Guàrdia, and M. Koole, "Online university teaching during and after the covid-19 crisis: refocusing teacher presence and learning activity," Postdigital Sci. Educ. 2020 23, vol. 2, no. 3, pp. 923-945, Jul. 2020, doi: 10.1007/S42438-020-00155-Y.

[6] S. Setiyani, S. Sumarwati, L. Sagita, and D. Fadhlurrohman, "The incredible boong gi: Educational game RPG for mathematical understanding ability," Int. J. Educ. Learn., vol. 3, no. 2, pp. 76-93, Aug. 2021, doi: 10.31763/IJELE.V3I2.217.
[7] A. H. Tamuri and N. M. R. Yusoff, Kaedah Pengajaran dan Pembelajaran Pendidikan Islam. Bangi: Universiti Kebangsaan Malaysia, 2010.

[8] G. Shabiralyani, K. S. Hasan, N. Hamad, and N. Iqbal, "Impact of visual aids in enhancing the learning process case research: District Dera Ghazi Khan," J. Educ. Pract., vol. 6, no. 19, pp. 226-233, 2015, Accessed: Oct. 21, 2021. [Online]. Available: https://eric.ed.gov/?id=EJ1079541.

[9] B. D. Cahyono and C. Ainur, "Development of ultrasonic testing based on Delphi program as a learning media in the welding material study of detection and welding disables in the environment of vocational education," IOP Conf. Ser. Mater. Sci. Eng., vol. 336, no. 1, p. 012028, Apr. 2018, doi: 10.1088/1757-899X/336/1/012028.

[10] A. S. Hanif, M. N. A. Azman, H. Pratama, and N. N. Mohd, "Kit pemantauan penyambungan litar elektrik: Satu kajian efikasi Alat Bantu Mengajar," Malaysian J. Soc. Sp., vol. 12, no. 3, pp. 69-78, 2016.

[11] M. N. A. Azman, N. A. Azli, R. Mustapha, B. Balakrishnan, and N. K. M. Isa, "Penggunaan alat bantu mengajar ke atas guru pelatih bagi topik kerja kayu, paip dan logam," Sains Humanika, vol. 3, no. 1, Dec. 2014, doi: 10.11113/SH.V3N1.530.

[12] A. R. Jamian and R. Baharom, "The application of teaching aids and school supportive factors in learning reading skill among the remedial students in under enrolment schools," Procedia - Soc. Behav. Sci., vol. 35, pp. 187-194, 2012, doi: 10.1016/J.SBSPRO.2012.02.078.

[13] C. G. C. Kob, A. Shah, H. Shamsuddin, and N. A. A. Norizan, "The effect of using learning kit material among students," Int. J. Recent Technol. Eng., vol. 7, no. 6S2, pp. 239-242, 2019. 
[14] C. M. Reigeluth, "Instructional theory and technology for the new paradigm of education (160)," Rev. Educ. a Distancia, no. 50, Jul. 2016, doi: 10.6018/RED/50/1B.

[15] A. R. Mohd Noor, S. Z. C. Ahmad, "Teacher creativity in improving understanding and appreciation of history," in 7th International Seminar on Regional Education, 2015, pp. 457-468.

[16] Y. C. Chou, H. Y. Yen, H. W. Yen, Y. L. Chao, and Y. H. Huang, "The effectiveness of teaching aids for elementary students' renewable energy learning and an analysis of their energy attitude formation," Int. J. Environ. Sci. Educ., vol. 10, no. 1, pp. 39-49, Jan. 2015, doi: 10.12973/IJESE.2015.229A.

[17] M. B. Mahusin, L. H. Asary, Z. Zubir, A. Masek, and A. Dardiri, "Developing a smart window air conditioner training kit for vocational students: An effective teaching kit," Univers. J. Educ. Res., vol. 8, no. 9, pp. 4303-4312, 2020, doi: 10.13189/ujer.2020.080957.

[18] S. Manthra Prathoshni, V. Vishnu Priya, and R. Gayathri, "Effect of teaching aids on student's academic performance in professional courses.," Drug Invent. Today, vol. 10, no. 12, pp. 2358-2361, 2018.

[19] A. H. Dawi, Theory of Sociology and Education. Tanjung Malim: Quantum Books, 2002.

[20] M. H. Amiruddin et al., "Students' acceptance of teaching interaction through the diversity of media in $\mathrm{m}$ learning," Online J. TVET Pract., vol. 6, no. 1, pp. 39-44, Mar. 2021, Accessed: Oct. 14, 2021. [Online]. Available: https://publisher.uthm.edu.my/ojs/index. php/oj-tp/article/view/8010.
[21] M. Sulaiman, Back to Basics "Fokus kepada Inovasi Sumber Pengajaran dan Pembelajaran. Jabatan Pengajian Melayu, 2009.

[22] S. H. H. Alshatri, K. Wakil, K. Jamal, and R. Bakhtyar, "Teaching aids effectiveness in learning mathematics," Accessed: Oct. 14, 2021. [Online]. Available: www.ijere.com.

[23] S. Sumarwati, H. Fitriyani, F. M. A. Setiaji, M. H. Amiruddin, and S. A. Jalil, "Developing mathematics learning media based on e-learning using moodle on geometry subject to improve students' higher order thinking skills," Int. J. Interact. Mob. Technol., vol. 14, no. 04, pp. 182-191, Mar. 2020, Accessed: Oct. 14, 2021. [Online]. Available: https://onlinejournals.org/index.php/ijim /article/view/12731.

[24] F. Ja'afar, "Bahan Bantu Mengajar (BBM) Dalam Pengajaran Dan Pembelajaran (P\&P) Di Sekolah Menengah Kebangsaan (SMK) Daerah Pontian," Universiti Tun Hussein Onn Malaysia, 2017.

[25] M. M. Durdanovic, "The use of teaching aids and their importance for students music education," Int. J. Cogn. Res. Sci. Eng. Educ., vol. 3, no. 2, 2015.

[26] M. Jafre, Z. Abidin, A. A. Rezaee, H. N. Abdullah, K. Kaur, and B. Singh, "Learning styles and overall academic achievement in a specific educational," Int. J. Humanit. Soc. Sci., vol. 1, no. 10, 2011, Accessed: Oct. 15, 2021. [Online]. Available: www.ijhssnet.com. 